\title{
Analyst Coverage Of Small Cap Firms In A Period Of Brokerage Firm Retrenchment
}

Rich Fortin, (E-mail: rfortin@nmsu.edu), New Mexico State University Greg Roth, (E-mail: gregroth@nmsu.edu), New Mexico State University

\begin{abstract}
We examine analysts' incentives to cover small cap firms in the year 2002, a period following stock market declines and brokerage firm retrenchment. Brokerage companies were losing a substantial number of sell-side analysts during this period and small firms were having unusual difficulty in attracting analyst coverage. Consistent with analysts' normal economic incentives and earlier research, we find that firm size, trading volume, and beta are all positively related to the number of analysts that cover a firm, whereas firm complexity is negatively related to analyst coverage. In contrast to some earlier research, we find no evidence that analysts were more likely to follow glamour (or growth) stocks. Specifically, price-to-book and revenue growth are not related to analyst coverage, and recent stock performance (price momentum) is negatively related to analyst coverage. Our interpretation of this evidence is that analysts had reduced incentives to cover glamour stocks following the severe stock market declines in the early 2000s, the increased regulatory scrutiny of securities firms, and the resulting brokerage firm retrenchment.
\end{abstract}

Key Words: investment decisions, information and market efficiency, investment banking and brokerage

\section{INTRODUCTION}

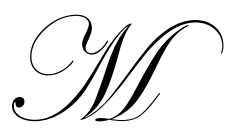

any investors rely heavily on analyst research and prior evidence suggests that firm managers place a high value on receiving analyst coverage (Cliff and Denis, 2004). In the early part of this century the quantity of sell-side analyst research decreased substantially. In the approximately two years following the US stock market peak of March 2000, the number of firms receiving analyst coverage in the US dropped by an estimated 20\% (Craig, 2003). Research budgets at investment banks fell by an estimated 35\% between 2000 and 2005 (The Economist, 2007). A combination of analyst layoffs by brokerage firms and voluntary retirements by analysts resulted in far fewer sell-side analysts covering US firms (Leone, 2004). Two reasons often given for this drop in analyst coverage include: (1) falling brokerage firm revenues during a period of poorly performing stock markets; and (2) regulatory pressure on securities firms to end payments for analyst research with investment banking fees. ${ }^{1}$ In short, there was less money to fund research by sell-side security analysts.

Because of the important role analyst research plays in informing investors, academics have long been interested in the factors determining analyst coverage. Prior researchers have observed that small cap firm managers generally have difficulty in attracting analyst coverage (see, for example, Bhushan, 1989, Rajan and Servaes, 1997, Barth, et al., 2001, and Bradley, et al., 2003), but reporters in the financial press stated that the problem became even more severe for small firms during the period of brokerage firm retrenchment (Craig, 2003, Leone, 2004).

\footnotetext{
${ }^{1}$ For details on the SEC settlement with securities firms that ultimately banned payment of equity research with investment banking fees, see http://www.sec.gov/news/press/2003-54.htm.
} 
This study is similar to earlier research that investigates analyst incentives to provide firm coverage, however we focus exclusively on small cap firms following a period of declining stock markets, the poor performance of many glamour stocks, declining analyst coverage, and renewed scrutiny of sell-side analysts. Specifically, we investigate the determinants of analyst coverage for 817 small cap firms at the end of the year 2002. We find that firm size, trading volume, and stock beta are all positively related to the number of analysts covering the firm's stock. These findings suggest that analysts are more motivated to provide coverage for firms expected to produce greater brokerage income or investment banking fees. We also find that the number of major business segments the firm operates (a proxy for business complexity) is negatively related to analyst coverage. This finding suggests that as the cost of providing coverage increases, brokerage firms are less motivated to provide analyst coverage. In contrast to earlier research, e.g., Jegadeesh, et al. (2004), we find no evidence that analyst coverage is greater for glamour stocks. Price-to-book ratio and revenue growth are unrelated to analyst coverage. Recent stock performance (price momentum) is negatively related to analyst coverage. Internet sector firms receive no more analyst coverage than other firms. We suggest that the poor performance of many glamour stocks after the 1990s and the high profile allegations that analysts mislead investors by inappropriately promoting growth stocks in the late 1990s may have dissuaded analysts from emphasizing these types of firms.

\section{HYPOTHESES}

McNichols and O’Brien (1997), Rajan and Servaes (1997), Bradley, et al. (2003), and Cliff and Denis (2004) all find evidence that analysts prefer to cover firms that they view favorably. Given these findings we assume that, ceteris paribus, greater analyst coverage of a firm is an indicator of greater analyst optimism for that firm. We consider that sell-side analysts may be less optimistic about glamour stocks and less motivated to cover glamour stocks in 2002 because: (a) the stock market performance since March 2000 had been poor and the performance of some high profile glamour stocks had been especially poor; and (b) the increased scrutiny of analysts behavior (by regulators, plaintiffs attorneys, the press, and investors) and the increased threat of being laid off likely put more pressure on analysts to justify their recommendations.

Our main focus in this study is testing whether sell-side analyst coverage of small cap firms is greater for glamour stocks in the early 2000s. We test the hypothesis using alternative proxy variables for glamour and we control for a variety of firm characteristics, most of which were found related to analyst coverage in earlier studies. The factors that we consider are: firm size, trading volume, beta, price-to-book, recent stock performance, revenue growth, the status of the firm as operating in the Internet sector, and the number of business segments which the firm operates.

\section{Firm Size}

Firm size is the total market value of the firm's stock at the end of the year 2002. Larger firms are more likely to generate greater investment banking fees and brokerage income for securities firms, and several earlier researchers (for example, Bhushan, 1989, Rajan and Servaes, 1997, Barth, et al., 2001, Bradley, et al., 2003), have found that larger firms attract greater analyst coverage. We expect a positive relationship between firm size and analyst coverage.

\section{Trading Volume}

Trading volume is the number of shares of the firm's stock traded in the calendar year 2002. Firm's with greater trading volume clearly generate greater commission income, so brokerage firms are more likely to maintain analyst coverage for high trading volume firms. Earlier researchers (for example, Barth, et al., 2001, and Jegadeesh, et al., 2004) find that high trading volume firms attract greater analyst coverage. 


\section{Beta}

Beta is the firm's stock beta, measured at the end of 2002. We use Research Insight's beta estimate, which is calculated over 60 months (if available) and uses a minimum of 24 months. Bhushan (1989) argues that investor demand for analyst coverage will be greater for firms with greater share price volatility, because the potential investor gains from firm-specific information is greater for these firms. He finds that volatility is positively related to the number of analysts covering a firm's stock. We use beta as a measure of share price volatility relative to the market and expect that it will have a positive influence on analyst coverage.

\section{Price-To-Book, Recent Stock Performance, Revenue Growth}

Price-to-book, one-year stock performance (or price momentum), and one-year revenue growth are all proxy variables for glamour stocks. We define "glamour stocks" as those firms having high price-to-book ratios, positive recent stock performance, or high revenue growth. Jegadeesh, et al. (2004) find that, in general, sell-side analysts tend to recommend stocks that are relatively expensive, stocks with positive price momentum, and stocks of high growth firms. Although prior evidence suggests glamour stocks are generally more popular with analysts, whether these characteristics are positively related to analyst coverage in 2002 is an empirical issue. After the bursting of the so-called Internet bubble in March 2000, media reports that analysts may have misled investors by hyping overvalued stocks, and retrenchment in the securities industry, analysts may have had less incentive to cover glamour stocks.

\section{Internet Sector}

Internet sector is an indicator variable that takes a value of one if the firm operates in an Internet sector. Because shares in many "dotcom" firms performed particularly poorly after March 2000, and because these firms attracted significant media attention, we test whether firms in an Internet sector attract an unusual level of analyst coverage.

\section{Business Segments}

Business segments is the number of major business segments the firm operates. We include business segments as a proxy variable for firm complexity and the cost of providing analyst coverage. As the number of business segments increases, the more difficult and costly it likely becomes for analysts to determine a stock's value and provide recommendations. Accordingly, Bhushan (1989) finds a negative relationship between the number of business lines for a firm and analyst coverage.

\section{DATA AND METHODOLOGY}

We gather a sample of small cap firms and data for all explanatory variables from Research Insight. Analyst coverage data were drawn from $\mathrm{I} / \mathrm{B} / \mathrm{E} / \mathrm{S}$. Analyst coverage is the number of analysts providing at least one annual earnings forecast for the firm. For the sample of small cap firms, we select all firms that had a market value of equity from $\$ 300$ million to $\$ 1.5$ billion at the end of 2002. This is the size restriction that Standard \& Poor's uses in developing the S\&P 600 small cap index. This initial screen results in a sample of 1034 firms.

We eliminate from the sample closed end funds, exchange traded funds, non-US companies, and firms lacking a sector description on Research Insight. We also eliminate firms for which data were lacking on any of the following variables: market capitalization; trading volume; beta, price-to-book; revenue growth; and one-year (unadjusted) stock returns, as well as firms with negative price-to-book ratios. To maintain time consistency between Research Insight data and I/B/E/S data, and for computational simplicity, we eliminate firms that did not have a fiscal year ending in December 2002. (The December fiscal year end requirement results in the loss of only seven firms.) 
The final sample has 817 firms. The mean and median market capitalizations are \$711 million and \$634 million, respectively. The mean and median number of analysts covering each firm is 7.24 and 6.0 , respectively. Other descriptive statistics for the final sample appear in Table 1.

Following the same methodology used by Bhushan (1989) and Barth, et al. (2001), we regress the number of analysts covering a firm on a series of right hand side variables thought to influence analyst coverage.

\section{RESULTS}

Table 2 shows the results from five different model specifications in which analyst coverage is regressed on the explanatory variables described earlier. In each model specification, firm size and beta are positively related to analyst coverage at the 0.01 level of significance. Trading volume is positively related to analyst coverage at the 0.05 level of significance. These results support research from earlier periods that examine the influences of firmspecific characteristics on analyst coverage. That is, these results suggest sell-side analysts are more likely to cover firms that are more likely to generate larger brokerage or underwriting fees.

Because of missing data in Research Insight, including the variable business segments in the model causes the sample size to drop to 614 firms. Consequently, we only include this variable in Models (4) and (5). In both models the number of business segments the firm operates is negatively related to analyst coverage at the 0.01 level of significance. Thus, our evidence supports Bhushan's (1989) findings and the notion that, holding other factors constant, analysts are less likely to provide firms with coverage as the complexity and cost of providing that coverage increases. The indicator variable Internet is not statistically significant in any specification in which it appears.

Regarding the main focus of the study, we find no evidence that analysts provide greater coverage to glamour stocks in the year 2002. Price-to-book and revenue growth are not significantly related to analyst coverage in any of the models in which they appear. Moreover, recent stock performance is negatively related to analyst coverage at the 0.01 level of significance (or less) in each of the models in which it appears. ${ }^{2}$

Our results regarding glamour stocks can be contrasted with those of Jegadeesh, et al. (2004) who find that analyst generally prefer to recommend expensive stocks, stocks of high growth firms, and stocks with positive share price momentum. Jegadeesh, et al. (2004) draw a sample of firms from 1985 to 1998 . This sample period permits a generalized inference about the typical behavior of analysts, at least prior to the declining stock markets of the early 2000s. Our sample data are drawn from the end of the year 2002, a point in time following poor stock market performance, increased scrutiny of analyst behavior, and securities industry retrenchment.

The most plausible interpretation of our results regarding glamour stocks is that analysts' incentives were somewhat different in 2002. In particular, the evidence from this study suggests that analysts had weaker incentives to recommend glamour stocks at this moment in time. Furthermore, our focus on small cap stocks (which generally have lower analyst coverage), allows us to suggest which firms likely had the greatest difficulty attracting analyst

\footnotetext{
${ }^{2}$ We conduct several robustness checks that are not shown in Table 2. For example, we estimate many additional model specifications and in no case can we reach a qualitatively different conclusion regarding the sign or significance of any of the explanatory variables. We use the price-earnings ratio as a valuation measure in place of the price-to-book ratio. None of our model estimates show price-earnings to be significant. We use standard regression diagnostics, such as those identified by Belsley, Kuh, and Welsh (1980), and conclude that OLS assumption violations are not driving our reported results. White's (1980) test does indicate the presence of heteroskedasticity, but we present results in Table 2 using White-corrected standard errors. We use the Hausman specification test to determine whether price-to-book and analyst coverage are endogenous variables. Using this test we find no evidence of a simultaneity problem. Although Bhushan (1989) and Barth, et al. (2001) use standard OLS to analyze determinants of analyst coverage, Rock, et al. (2000) recommend using a negative binomial model in estimating cross-sectional, analyst-following regressions. We re-estimate the influence of all explanatory variables on analyst coverage using negative binomial regressions and the results shown in Table 2 are strongly supported. All significant variables shown in Table 2 retain their sign and are significance at the $1 \%$ level (or better). All insignificant variables in Table 2 are again found to be statistically insignificant, including price-to-book (which has $p=0.649$ using model (5) with the negative binomial regression).
} 
coverage after the market peak in the year 2000. These were smaller firms with low trading volume, low beta, positive price momentum, and many business segments.

Using Australian data, Azzi and Bird (2005) provide evidence that is somewhat similar in spirit to our findings. They find that Australian analysts disproportionately recommended growth stocks with positive price momentum in the "boom" years of the 1990s, but in the "gloom" years of the early 2000s they moved their recommendations away from these types of firms.

\section{CONCLUSIONS}

We study the incentives of equity analysts to provide coverage of small cap firms in the year 2002. This period followed major stock market declines, the poor performance of many glamour stocks, increased scrutiny of analyst behavior by regulators and the financial press, and an industry-wide reduction in the number of equity analysts providing research. Our evidence suggests that several firm-specific characteristics previously shown to influence analyst coverage continued to influence analysts in a predictable manner. Firm size, trading volume, and beta are all positively related to the number of analysts that cover a firm, whereas firm complexity is negatively related to analyst coverage. These factors are entirely consistent with the economic incentives analysts normally encounter when selecting which firms to cover. However, we also find that analysts did not favor glamour stocks when selecting firms for coverage. Neither price-to-book nor revenue growth is related to analyst coverage, and recent stock performance (price momentum) is negatively related to analyst coverage. These findings contrast those of earlier researchers, e.g., Jegadeesh, et al. (2004), who rely on sample periods ending in the 1990s. We argue that analysts had unusual incentives to deemphasize glamour stocks during the early 2000 s.

\section{ACKNOWLEDGEMENT}

The authors gratefully acknowledge the contribution of Thomson Financial for providing analyst data, available through the Institutional Brokers Estimate System. This data has been provided as part of a broad academic program to encourage earnings expectation research.

\section{REFERENCES}

1. Azzi, S. and R. Bird, 2005, Prophets During Boom and Gloom Downunder, Global Finance Journal 15, 337-367.

2. Barth, M., R. Kasznik, and M. McNichols, 2001, Analyst Coverage and Intangible Assets, Journal of Accounting Research 39, 1-34.

3. $\quad$ Belsley, D., E. Kuh, R. Welsh, 1980, Regression Diagnostics, John Wiley \& Sons, New York.

4. Bhushan, R., 1989, Firm Characteristics and Analyst Following, Journal of Accounting and Economics 11, 255-274.

5. Bradley, D., B. Jordan, and J. Ritter, 2003, The Quite Period Goes Out with a Bang, Journal of Finance 58, $1-36$.

6. Cliff, M. and D. Denis, 2004, Do Initial Public Offering Firms Purchase Analyst Coverage with Underpricing?, Journal of Finance 59, 2871-2901.

7. Craig, S., 2003, March 26, Analyzing the Analysts: Amid Shrinking Research Pool, Companies Buy Their Coverage, The Wall Street Journal Online.

8. Hausman, J., 1976, Specification Tests in Econometrics, Econometrica 46, 1251-1271.

9. Jegadeesh, N., J. Kim, S. Krische, and C. Lee, 2004, Analyzing the Analysts: When Do Recommendations Add Value?, Journal of Finance 59, 1083-1124.

10. Leone, M., 2004, July 8, The Drought of Sell-Side Coverage, CFO Magazine (CFO.com)

11. McNichols, M. and P. O'Brien, 1997, Self-selection and Analyst Coverage, Journal of Accounting Research 35, 167-199.

12. Rajan, R. and H. Servaes, 1997, Analyst Following of Initial Public Offerings, Journal of Finance 52, 507529.

13. Research in Commotion, 2007, June 23, The Economist, 83. 
14. Rock, S., S. Sedo, and M. Willenborg, 2000, Analyst Following and Count-Data Econometrics, Journal of Accounting and Economics 30, 351-373.

15. White, H., 1980, A Heteroskedasticity-Consistent Covariance Matrix Estimator and A Direct Test for Heteroskedasticity, Econometrica 48, 817-838.

Table 1

\section{Summary Statistics}

Shown are summary statistics for sampled small cap firms. Each firm was selected from Research Insight and has a total market value of equity between $\$ 300$ million and $\$ 1.5$ billion. All variables are measured for the year 2002. Analyst Coverage is the number of analysts covering the firm. Firm Size is the total market value of equity. Trading Volume is the annual number of shares traded. Beta is the firm's stock beta. Price-to-book is the market value of equity divided by the book value of equity. Stock Return is the preceding one-year percentage raw return on the firm's stock. Internet takes a value of one if the firm operates in an Internet sector (as classified by Research Insight). Revenue Growth is the percentage change in sales for the current year. Business Segments is the number of major business segments the firm operates (as classified by Research Insight). Analyst Coverage data are drawn from $\mathrm{I} / \mathrm{B} / \mathrm{E} / \mathrm{S}$ and all other data are drawn from Research Insight.

\begin{tabular}{|c|c|c|c|c|c|c|}
\hline Variable & $\mathbf{N}$ & Mean & Median & $\begin{array}{l}\text { Standard } \\
\text { Deviation }\end{array}$ & Max. & Min. \\
\hline Analyst Coverage & 817 & 7.24 & 6.00 & 6.22 & 35 & 0 \\
\hline Firm Size (in \$millions) & 817 & 710.77 & 634.06 & 331.48 & 1497.83 & 302.27 \\
\hline Trading Volume (in millions) & 817 & 100.60 & 47.84 & 202.01 & 2602.58 & 0.01 \\
\hline Beta & 817 & 0.84 & 0.59 & 0.87 & 5.62 & -0.61 \\
\hline Price-to-book & 817 & 5.14 & 3.01 & 12.11 & 210.96 & 0.03 \\
\hline Stock Return (in \%) & 817 & -1.68 & -4.11 & 82.25 & 1971.88 & -95.32 \\
\hline Internet & 817 & 0.02 & 0.00 & 0.13 & 1 & 0 \\
\hline Revenue Growth (in \%) & 817 & 14.80 & 3.03 & 118.83 & 2337.67 & -94.11 \\
\hline Business Segments & 614 & 2.67 & 2.00 & 1.75 & 10 & 1 \\
\hline
\end{tabular}


Table 2

Regressions of Analyst Coverage for Small Cap Firms

Shown are the results of regressing analyst coverage on several variables. The sample includes 817 small cap firms, each with a total market value of equity between $\$ 300$ million and $\$ 1.5$ billion at the end of year 2002 . The dependent variable is the number of analysts covering the firm's stock. Firm Size is the total market value of equity. Trading Volume is the annual number of shares traded. Beta is the firm's stock beta. Price-to-book is the market value of equity divided by the book value of equity. Stock Return is the preceding one-year percentage raw return on the firm's stock. Internet takes a value of one if the firm operates in the Internet sector (as classified by Research Insight). Revenue Growth is the percentage change in sales for the current year. Business Segments is the number of major business segments the firm operates (as classified by Research Insight). All variables are measured for the year 2002. Coefficient estimates are shown on the top row for each variable. P-values are shown in parentheses and are calculated using White's (1980) corrected standard errors.

\begin{tabular}{|c|c|c|c|c|c|}
\hline & (1) & (2) & (3) & (4) & (5) \\
\hline Intercept & $\begin{array}{l}1.848 \\
(0.000)\end{array}$ & $\begin{array}{l}1.917 \\
(0.000)\end{array}$ & $\begin{array}{l}1.836 \\
(0.000)\end{array}$ & $\begin{array}{l}2.252 \\
(0.000)\end{array}$ & $\begin{array}{l}2.178 \\
(0.001)\end{array}$ \\
\hline Firm Size & $\begin{array}{l}0.003 \\
(0.000)\end{array}$ & $\begin{array}{l}0.003 \\
(0.000)\end{array}$ & $\begin{array}{l}0.004 \\
(0.000)\end{array}$ & $\begin{array}{l}0.005 \\
(0.000)\end{array}$ & $\begin{array}{l}0.005 \\
(0.000)\end{array}$ \\
\hline Trading Volume & $\begin{array}{l}0.007 \\
(0.013)\end{array}$ & $\begin{array}{l}0.007 \\
(0.019)\end{array}$ & $\begin{array}{l}0.007 \\
(0.019)\end{array}$ & $\begin{array}{l}0.006 \\
(0.045)\end{array}$ & $\begin{array}{l}0.006 \\
(0.046)\end{array}$ \\
\hline Beta & $\begin{array}{l}2.556 \\
(0.000)\end{array}$ & $\begin{array}{l}2.564 \\
(0.000)\end{array}$ & $\begin{array}{l}2.535 \\
(0.000)\end{array}$ & $\begin{array}{l}2.638 \\
(0.000)\end{array}$ & $\begin{array}{l}2.652 \\
(0.000)\end{array}$ \\
\hline Price-to-book & $\begin{array}{l}0.011 \\
(0.384)\end{array}$ & & $\begin{array}{l}0.014 \\
(0.269)\end{array}$ & & $\begin{array}{l}0.007 \\
(0.576)\end{array}$ \\
\hline Stock Return & & $\begin{array}{l}-0.009 \\
(0.000)\end{array}$ & $\begin{array}{l}-0.009 \\
(0.000)\end{array}$ & $\begin{array}{l}-0.008 \\
(0.000)\end{array}$ & $\begin{array}{l}-0.008 \\
(0.000)\end{array}$ \\
\hline Internet & & & $\begin{array}{l}0.486 \\
(0.813)\end{array}$ & & $\begin{array}{l}-0.146 \\
(0.951)\end{array}$ \\
\hline Revenue Growth & & & $\begin{array}{l}0.001 \\
(0.250)\end{array}$ & & $\begin{array}{l}0.000 \\
(0.611)\end{array}$ \\
\hline Business Segments & & & & $\begin{array}{l}-0.350 \\
(0.007)\end{array}$ & $\begin{array}{l}-0.344 \\
(0.009)\end{array}$ \\
\hline $\mathrm{R}^{2}$ & 0.295 & 0.308 & 0.309 & 0.342 & 0.342 \\
\hline $\mathrm{N}$ & 817 & 817 & 817 & 614 & 614 \\
\hline
\end{tabular}


NOTES 